\title{
Family Income and Health Insurance as Factors Related to Family Response to Acute Coronary Syndrome Attack
}

\author{
Servasius To'o Jala Mulu ${ }^{1}$, Titin Andri Wihastuti ${ }^{2}$, Dhelya Widasmara ${ }^{3}$ \\ ${ }^{1}$ Master Program of Nursing, Faculty of Medicine, University of Brawijaya, Indonesia \\ ${ }^{2}$ Nursing Master Program, Faculty of Medicine, University of Brawijaya, Indonesia \\ ${ }^{3}$ Medical Program, Faculty of Medicine, University of Brawijaya, Indonesia \\ Email: oriesmulu77@gmail.com
}

\begin{abstract}
Response to attack Acute Coronary Syndrome (ACS) significantly contributes to the incidence of complications and death in ACS patients. This response is concerned with making decisions regarding emergency care. The family is one of the decision makers regarding emergency care for ACS patients. Economic problems and the ownership of health insurance can cause a poor response. Analytic observational design, cross sectional was used in 104 patient families (parents / husband / wife / children) who are in charge of care for ACS patients at the Ende Regional General Hospital using a modified Acute Coronary Syndrome Response Index questionnaire. Less response was found in $42.3 \%$ of respondents. There was a significant relationship between response and family income $(P=0.000, O R=0.599)$ but not with health insurance ownership $(P=0.359 ; O R=$ 0.090). Response is less closely related to economic problems experienced even though the patient has been insured. Therefore, it is important to develop strategies to increase the response (knowledge, attitudes and beliefs) of families related to SKA, especially in low-income groups. This will help them speed up decision making when SKA's re-attack occurs.
\end{abstract}

Keywords: Family Response, SKA, Income, Health Insurance.

\section{A. INTRODUCTION}

Acute coronary syndrome (ACS) is a common form of cardiac emergency that is associated with high mortality rates in hospitals (Andrikopoulos et al., 2016). When compared with other causes, ACS is responsible for the majority of cardiac arrest events where the survival of the sufferer is $<10 \%$ (Narayan et al., 2019; Wong et al., 2019). Based on data from Global Burden Disease (2015), it is estimated that 110.6 million people in the world experience ischemic heart disease (American Heart Association, 2018) and it causes the death of approximately 8,916,964 people in the world (Roth et al., 2017). Other data from the World Health Organization (WHO) shows that ischemic heart disease is ranked first as the number one cause of death in the world since 2000 and the cause of death of approximately 9,433,244 people in the world in 2016 (World Health Organization, 2018).

In Indonesia, heart disease is the second highest cause of morbidity and mortality after stroke (Kementerian Kesehatan Republik Indonesia, 2018). Based on data from the results of the Basic Health Research (RISKESDAS) in 2013, the prevalence of Indonesians experiencing ACS from the results of interviews with diagnosed doctors was $0.5 \%$ or around 883,447 people, and diagnosed doctors or 
symptoms was $1.5 \%$ or around $2,650,340$ people. Of this number, East Nusa Tenggara Province ranks first (4.4\%) (Kementerian Kesehatan Republik Indonesia, 2013). In 2018 there were 44,782 people suffering from coronary heart disease (Kemenkes RI, 2018). From the data on the recapitulation of SKA incidents at the Ende Regional General Hospital, there were 560 SKA incidents during 2019. In addition, in the same year, SKA was the cause of death for 88 people in the IGD.

The high mortality rate in ACS patients can basically be minimized by initiating treatment immediately after the initial onset occurs (Alfasfos et al., 2016). Based on the 2013 American College of Cardiology Foundation and American Heart Association (ACCF / AHA) guidelines, the standard time to arrive at the ER after initial onset is 120 minutes (O'Gara et al., 2013). However, the condition that occurs is that ACS patients often arrive at the hospital beyond this standard time. The main cause reported is related to the delay in making decisions to follow up on symptoms that arise (Damasceno et al., 2012; Mooney et al., 2014; Ravi et al., 2015). This basically takes more than half of the time that ACS patients should arrive at the hospital that they should have (Ravi et al., 2015).

As followers of communalism, family support is an inseparable aspect of community life in Indonesia (Claramita et al., 2013). As the main support system, family is often associated with decision making in ACS patients SKA (Perkins-Porras et al., 2009; Ravi et al., 2015). A study revealed that $81.05 \%$ of families are the main decision makers regarding the care of family members (Pradnyani \& Suariyani, 2016). In line with these findings, several other studies reported that family is one of the predictors of admission time for ACS patients to the hospital when an attack occurs (Perkins-Porras et al., 2009; Xie et al., 2015). In addition to being the primary caregiver for a sick family member, the family is the first person to identify disorders experienced by family members, as well as being the decision maker regarding care for members who experience disorders (Noureddine et al., 2015). The evidence above underlies us to conduct this study with the families of ACS patients as the main respondents.

It has been previously reported that the main cause of failure in decision making is due to a lack of knowledge regarding the symptoms of ACS, especially atypical symptoms, negative attitudes and beliefs related to ACS (Ghazawy et al., 2015; O'Brien et al., 2012; Perkins-Porras et al., 2009; Youssef et al., 2017). Literature studies show that access to health facilities is one of the causes underlying this condition. It is stated that economic conditions and ownership of health insurance are factors that contribute to access to health facilities. However, findings in several previous studies have debated the association of these two factors with the response given when an ACS attack occurred. For example, Alfasfos et al. (2016) in their research reported that good knowledge, and more positive attitudes and beliefs were most likely to be found in those with high family income and had health insurance. This is also consistent with several other studies (Banharak et al., 2018; Mahajan et al., 2019; Smolderen et al., 2010). On the other hand, other studies actually prove that the level of income and insurance ownership is not significantly related to the 
response of both knowledge, attitudes and beliefs to ACS (Noureddine et al., 2010; Noureddine \& Dumit, 2019).

Therefore, this study aims to determine the relationship between family income and health insurance ownership with the family's response to SKA attacks at the Ende Regional General Hospital, East Nusa Tenggara-Indonesia. The results of this study are expected to be one of the considerations for nurses in the development of educational interventions for patients and families of ACS patients in order to shorten the admission time of patients in SKA in the ER.

\section{B. METHOD}

This study was an observational analytic study with a cross-sectional approach. The sample in this study consisted of 104 patient families (parents / husband / wife / children who are responsible for the care of patients with ACS) who undergo inpatient and outpatient care using purposive sampling technique. Data collection used a modified Acute Coronary Syndrome Response Index questionnaire and a demographic data questionnaire for family income and patient health insurance ownership status. Data were taken from July to September 2020. Data analysis used the Contingency Coefficient Test. This research has received ethical permission from the Health Research Ethics Commission of the Health Polytechnic of the Ministry of Health Kupang with the number LB.02.03 / 1/0044/2020.

\section{RESULT AND DISCUSSION}

The response characteristic data in Table 1 shows that almost half of the respondents $(36.5 \%)$ have a family income of more than 3.5 million, and most $(75.0 \%)$ are families of patients who have health insurance.

Table 1 Sample Characteristics Based on Family Income and Insurance Ownership $(n=104)$

\begin{tabular}{cccc}
\hline Characteristics & Category & f & \% \\
\hline Family Income & 0-1,5 Million & 14 & 13,5 \\
& 1,6-2,5 Million & 28 & 26,9 \\
& 2,6-3,5 Million & 24 & 23,1 \\
& $>3,5$ Million & 38 & 36,5 \\
\hline Health Insurance & Have & 26 & 25,0 \\
Ownership & Do not have & 78 & 75,0 \\
\hline
\end{tabular}

Based on Table 2 it is known that of the 104 families of ACS patients, more than half (57.7\%) with a good category response faced ACS attacks. In addition, from the response domain, it is known that most of the families (51.9\%) have good knowledge about acute coronary syndrome symptoms, almost all families $(76.9 \%)$ have good attitudes in responding to attacks of acute coronary syndrome, and all family $(100 \%)$ have confidence in both recognizing and responding when an acute coronary syndrome attack occurs. 
Table 2 Frequency Distribution of Family Response and Family Response Domain $(n=104)$

\begin{tabular}{lcc}
\hline Family Response & $\mathrm{f}$ & $\%$ \\
\hline Poor & 44 & 42,3 \\
Good & 60 & 57,7 \\
\hline Family Response Domain & & \\
\hline Knowledge & & 48,1 \\
\hline Lack & 50 & 51,9 \\
Good & 54 & \\
\hline Attitudes & & 23,1 \\
\hline Negative & 24 & 76,9 \\
$\quad$ Positive & 80 & \\
\hline Beliefs & & 0 \\
\hline Negative & 0 & 100 \\
Positive & 100 & \\
\hline
\end{tabular}

The results of the analysis of the relationship between family income and health insurance ownership status with family responses are as follows:

Table 3 The Relationship between Family Income and Patient Health Insurance Ownership Status with Family Response

\begin{tabular}{lllll}
\hline & \multicolumn{2}{c}{ Response } & & \\
\cline { 2 - 3 } Variable & Poor & Good & OR \\
& $f(\%)$ & $f(\%)$
\end{tabular}$\quad$ P Value

\section{Family Income}

0-1,5 Million

1,6-2,5 Million

$10(9,6)$
$25(24,0)$
$9(8,7)$
$0(0)$

2,6-3,5 Million

$0(0)$

$3(2,9)$
$15(14,4)$
$38(36,5)$

0,599

0,000

\section{Health Insurance \\ Ownership}

$\begin{array}{ccccc}\text { Have } & 9(8,7) & 17(16,3) & 0,090 & 0,359 \\ \text { Do not have } & 35(33,7) & 43(41,3) & & \end{array}$

In this study, response measurement is based on three cognitive response domains including knowledge, attitudes, and beliefs. The measurement results were then categorized into two categories based on the median value due to the abnormal distribution of the data. Knowledge is grouped into good and lacking, while values and beliefs are categorized into positive and negative. The results of the analysis showed that almost half of the respondents had low knowledge, less than a quarter had a negative attitude, and all of them had positive beliefs about SKA.

When compared to families with a family income of less than 3.5 million, families with a family income of more than 3.5 million were more likely to be on good terms when the SKA attack occurred. The P value of 0.000 means that there is a 
significant relationship between family income and family response with a strong correlation ( $\mathrm{OR}=0.599)$. This differs from insurance ownership, where the family response is not significantly different both for the families of ACS patients who have and do not have health insurance $(P=0.359$; $O R=0.090)$ (Table 3$)$. These findings indicate that even though ACS patients have health insurance, the response given by their families when an ACS attack occurs is still poor if they are not supported by high family income.

These findings are in line with the Jordan study by Alfasfos et al. (2016). In their study they reported that good responses (good knowledge, positive attitudes and beliefs regarding SKA) tended to be given by groups of individuals with high family income. This evidence is also consistent with findings in several other studies where response, awareness, and high knowledge of ACS are most likely to be found in groups with high family income and having health insurance (Banharak et al., 2018; Mahajan et al., 2019; Smolderen et al., 2010; Swanoski et al., 2012).

In their study, Alfasfos et al. (2016) explained that low knowledge and negative attitudes and beliefs regarding SKA in relation to financial constraints experienced are caused by low access to health facilities. This is consistent with the findings in the research of Latunji \& Akinyemi (2018) in Ibadan-Nigeria where family income is one of the factors that influence health care seeking behavior. It is further explained that access to health facilities increases simultaneously with an increase in economic status. Apart from that, other findings from Jeyashree et al. (2019) support this finding that economic conditions significantly influence decision making in seeking health care in ACS patients.

The condition of low income and high cost of care causes a low percentage of access for individuals with low family income to health facilities. That way, reducing the percentage of possibility for this group to be exposed to various information related to SKA. This is also exacerbated by the fact that costs are also required for access to various sources of health information which are basically unfavorable for individuals in this group (Intas et al., 2015). In addition, because of the economic constraints experienced, individuals in this group then prefer to self-medicate or seek cheaper alternative treatments (Widayanti et al., 2020). As a result of this condition, they adopt inappropriate attitudes regarding the symptoms of ACS (Alfasfos et al., 2016). However, with regard to health insurance ownership, the results of this study differ from the findings above.

Alfasfos et al. (2016) in their research showed a significant relationship in terms of response to groups who have and do not have health insurance. When compared with the group that did not have health insurance in their study, the group that had health insurance had better knowledge, attitudes and beliefs that were more positive about SKA. What distinguishes our findings from their findings is that respondents who have health insurance in their study are a group of individuals with high income levels (Alfasfos et al., 2016). In contrast, nearly threequarters of respondents $(65.4 \%)$ who had health insurance in our study were those with a family income of less than 3.5 million. This condition illustrates that more 
than half of the insured respondents belong to the family group with middle to lower economic conditions.

A study by Yusniawati et al. (2018) support this finding. In their study, they reported, of the 230 respondents in their study who experienced delays in arriving at the hospital when the SKA attack occurred, 225 of them were with middle to lower socioeconomic conditions. The main reason for this condition is that the health insurance owned does not cover all medical expenses (Yusniawati et al., 2018). This evidence explains that even though they already have health insurance, concerns related to high health care costs may be experienced by those with low family income even though they already have health insurance.

Apart from the explanation above, another explanation comes from the low utilization of preventive and rehabilitative services from low-income family groups who have health insurance. This is motivated by a lack of knowledge about health insurance itself, which has a 5\% greater chance in the middle and lower economic groups (Agustina et al., 2018; Dartanto et al., 2016). More than that, Erlangga et al. (2019) added that when compared to outpatient care, individual groups of subsidized insurance are more likely to access inpatient facilities only. This finding is consistent with previous studies where increased access to hospitalization occurred in individuals with financial problems (Campbell et al., 2017). This evidence underscores the important fact that the financial problems faced have resulted in individuals in this group focusing more on curative care than promotive and rehabilitative efforts. Curative treatment in this case is intended to relieve symptoms that arise because these symptoms are considered to interfere with their daily activities (Alfasfos et al., 2016). This is in accordance with their perception of health services as expressed by Widayanti et al. (2020).

This explanation basically explains the findings in this study where insurance ownership does not affect the response given by families when the ACS attack occurs. Concerns related to high costs coupled with a lack of knowledge from this group regarding services obtained as part of JKN membership result in a low percentage of access to health services. As a result, they are also less likely to be exposed to accurate information about SKA, especially from health workers through health counseling or direct discussions with health workers (Alfasfos et al., 2016; Yusniawati et al., 2018).

\section{CONCLUSION}

Based on the description above, it can be concluded that the financial problems experienced are the main obstacles for the community in accessing health facilities as well as reducing the possibility of being exposed to information and adopting an appropriate attitude towards SKA. Therefore, health education interventions, especially in groups with low economic conditions, are needed to enable them to identify the signs and symptoms of ACS, as well as accelerate decision-making regarding emergency care when an ACS attack occurs. 


\section{REFERENCES}

1. Agustina, R., Dartanto, T., Sitompul, R., Susiloretni, K. A., Suparmi, Achadi, E. L., Taher, A., Wirawan, F., Sungkar, S., Sudarmono, P., Shankar, A. H., \& Thabrany, H. (2018). Universal health coverage in Indonesia : Concept, progress, and challenges. The Lancet, 6736(18). https://doi.org/10.1016/S0140-6736(18)316477

2. Alfasfos, N., Darawad, M. W., Nofal, B., Samarkandi, O. A., \& Abdulqader, B. (2016). Knowledge, attitudes, beliefs and perceived risk of acute coronary syndrome among Jordanian patients. Health, 8(15), 1830-1844. https://doi.org/10.4236/health.2016.815175

3. Andrikopoulos, G., Terentes-Printzios, D., Tzeis, S., Vlachopoulos, C., Varounis, C., Nikas, N., Lekakis, J., Stakos, D., Lymperi, S., Symeonidis, D., Chrissos, D., Kyrpizidis, C., Alexopoulos, D., Zombolos, S., Foussas, S., Kranidis, A., Oikonomou, K., Vasilikos, V., Andronikos, P., ... Vardas, P. (2016). Epidemiological characteristics, management and early outcomes of acute coronary syndromes in Greece: The PHAETHON study. Hellenic Journal of Cardiology, 57, 157-166. https://doi.org/10.1016/j.hjc.2016.06.003

4. Banharak, S., Zahrli, T., \& Matsuo, H. (2018). Public knowledge about risk factors, symptoms, and first decision-making in response to symptoms of heart attack among lay people. Pacific Rim International Journal of Nursing Research, 22(1), 18-29.

5. Campbell, D. J. T., Manns, B. J., Weaver, R. G., Hemmelgarn, B. R., King-shier, K. M., \& Sanmartin, C. (2017). Financial barriers and adverse clinical outcomes among patients with cardiovascular-related chronic diseases: A cohort study. BMC Medicine, 15(33), 1-13. https://doi.org/10.1186/s12916-017-0788-6

6. Claramita, M., Nugraheni, M. D. F., van Dalen, J., \& van der Vleuten, C. (2013). Doctor-patient communication in Southeast Asia: A different culture? Advances in Health Sciences Education, 18(1), 15-31. https://doi.org/10.1007/s10459-012-93525

7. Damasceno, C. A., Queiroz, T. L. de, Santos, C. A. de S. T., \& Mussi, F. C. (2012). Factors associated with the decision to seek health care in myocardial infarction: Gender differences. Rev Esc Enferm USP, 46(6), 1363-1371.

8. Dartanto, T., Rezki, J. F., Pramono, W., Siregar, C. H., Usman, \& Bintara, H. (2016). Participation of informal sector workers in Indonesia's national health insurance system. J Southeast Asian Econ, 33, 317-342. https://doi.org/https://doi.org/10. 1355/ae33-3c

9. Erlangga, D., Ali, S., \& Bloor, K. (2019). The impact of public health insurance on healthcare utilisation in Indonesia: Evidence from panel data. International Journal of Public Health, 64(4), 603-613. https://doi.org/10.1007/s00038-019-01215-2

10. Ghazawy, E. R., Seedhom, A. E., \& Mahfouz, E. M. (2015). Predictors of delay in seeking health care among myocardial infarction patients, Minia District, Egypt. Advances in Preventive Medicine, 1-7. https://doi/10.1155/2015/342361

11. Intas, G., Tsolakoglou, J., Stergiannis, P., Chalari, E., Eleni, C., \& Fildissis, G. 
(2015). Do Greek citizens have minimum knowledge about heart attack? A survey. Health Science Journal, 9(5), 1-6.

12. Jeyashree, K., Paramasivam, Y., Mathavan, A., Vadivelu, R., \& Abdulkader, R. S. (2019). Treatment delayed is treatment denied: The tortorus pathway to care for acute coronary syndrome. Journal of Indian College of Cardiology, 9(1), 17-23. https://doi.org/10.4103/JICC.JICC

13. Kemenkes RI. (2018). Laporan Provinsi Nusa Tenggara Timur Riskesdas 2018. Lembaga Penerbit Badan Penelitian dan Pengembangan Kesehatan 2019.

14. Kementerian Kesehatan Republik Indonesia. (2013). Riset Kesehatan Dasar (RISKESDAS) 2013.

15. Kementerian Kesehatan Republik Indonesia. (2018). Potret Sehat Indonesia dari Riskesdas 2018. https:/www.depkes.go.id/article/view/18110200003/potret-sehatindonesia-dari-riskesdas-2018.html

16. Latunji, O. O., \& Akinyemi, O. O. (2018). Factors influencing health-seeking behaviour among civil servants in Ibadan, Nigeria. Annals of Ibadan Postgraduate Medicine, 16(1), 52-60.

17. Mahajan, S., Valero-Elizondo, J., Khera, R., Desai, N. R., Blankstein, R., Blaha, M. J., Virani, S. S., Kash, B. A., Zoghbi, W. A., Krumholz, H. M., \& Nasir, K. (2019). Variation and disparities in awareness of myocardial infarction symptoms among adults in the United States. JAMA Network Open, 2(12), 1-15. https://doi.org/10.1001/jamanetworkopen.2019.17885

18. Mooney, M. T., McKee, G., Fealy, G., O’Brien, F., O’Donnell, S., \& Moser, D. (2014). A randomized controlled trial to reduce prehospital delay time in patient with acute coronary syndrome (ACS). Journal of Emergency Medicine, 46(4), 495506. https://doi.org/http://dx.doi.org/10.1016/j.jemermed.2013.08.114 Selected

19. Narayan, S. M., Wang, P. J., \& Daubert, J. P. (2019). New concepts in sudden cardiac arrest to address an intractable epidemic. Journal of the American College of Cardiology, 73(1), 70-88. https://doi.org/10.1016/j.jacc.2018.09.083

20. Noureddine, S., \& Dumit, N. Y. (2019). Patients' knowledge and attitudes about myocardial infarction. Nursing $\mathcal{E}$ Health Sciences, 1-8. https://doi.org/10.1111/nhs.12642

21. Noureddine, S., Dumit, N. Y., \& Saab, M. (2015). Deciding to seek emergency care for acute myocardial infarction. Clinical Nursing Research, 24(5), 487-503. https://doi.org/10.1177/1054773814548508

22. Noureddine, S., Sivarajan, E., Sibai, A. M., \& Dakik, H. (2010). Response to a cardiac event in relation to cardiac knowledge and risk perception in a Lebanese sample: A cross sectional survey. International Journal of Nursing Studies, 47(3), 332-341. https://doi.org/10.1016/j.ijnurstu.2009.07.002

23. O’Brien, F., O’Donnell, S. O., Mckee, G., Mooney, M., \& Moser, D. (2012). Knowledge, attitudes, and beliefs about acute coronary syndrome in patients diagnosed with ACS: An Irish cross-sectional study. European Journal of Cardiovascular Nursing, 12(2), 201-208. https://doi.org/10.1177/1474515112446544

24. O'Gara, P. T., Kusher, F. G., Ascheim, D. D., Casey, D. E., Chung, M. K., De 
Lemos, J. A., \& Zhao, D. X. (2013). 2013 ACCF/AHA guideline for the management of st-elevation myocardial infarction: A Report of the American College of Cardiology Foundation/American Heart Association task force on practice guidelines. Journal of the American College of Cardiologi, 61(4), 78-140. https://doi.org/https://doi.org/10.1016/j.acc.2012.11.019

25. Perkins-Porras, L., Whitehead, D. L., Strike, P. C., \& Steptoe, A. (2009). Prehospital delay in patients with acute coronary syndrome: Factor associated with patient decision time and home-to-hospital delay. Eur J Cardiovasc Nurs, 8, 26-33. https://doi.org/10.1016/j.ejcnurse.2008.05.001

26. Pradnyani, N. W. W., \& Suariyani, N. L. P. (2016). Family role in decision making of health seeking behavior on elderly in Tabanan Regency, Bali, Indonesia. Epidemiology (Sunnyvale), 6(1), 3-7. https://doi.org/10.4172/21611165.1000218

27. Ravi, V. C., Adilakshmi, B., Ram, M. T., Trivikrama, R. M., \& Abbaiah, S. (2015). Factors affecting time to arrival in hospital among patients with acute myocardial infarction (MI). Journal of Scientific and Innovative Research, 4(2), 109114.

28. Roth, G. A., Johnson, C., Abajobir, A., Abd-Allah, F., Abera, S. F., Abyu, G., Ahmed, M., Aksut, B., Alam, T., Alam, K., Alla, F., Alvis-Guzman, N., Amrock, S., Ansari, H., Ärnlöv, J., Asayesh, H., Atey, T. M., Avila-Burgos, L., Awasthi, A., ... Murray, C. (2017). Global, regional, and national burden of cardiovascular diseases for 10 causes , 1990 to 2015. Journal of the American College of Cardiology, 70(1), 1-25. https://doi.org/10.1016/j.jacc.2017.04.052

29. Smolderen, K. G., Spertus, J. A., Nallamothu, B. K., Krumholz, H. M., Tang, F., Ross, J. S., Ting, H. H., Alexander, K. P., Rathore, S. S., \& Chan, P. S. (2010). Health care insurance, financial concerns in accessing care, and delays to hospital presentation in acute myocardial infarction. JAMA - Journal of the American Medical Association, 303(14), 1392-1400. https://doi.org/10.1001/jama.2010.409

30. Swanoski, M. T., Lutfiyya, M. N., Amaro, M. L., Akers, M. F., \& Huot, K. L. (2012). Knowledge of heart attack and stroke symptomology : A cross-sectional comparison of rural and non-rural US adults. BMC Public Health, 12(283), 1-8. https://doi.org/10.1186/1471-2458-12-283

31. Widayanti, A. W., Green, J. A., Heydon, S., \& Norris, P. (2020). Health-seeking behavior of people in Indonesia : A narrative review. Journal of Epidemiology and Global Health, 10(1), 6-15. https://doi.org/https://doi.org/10.2991/jegh.k.200102.001

32. Wong, C. X., Brown, A., Lau, D. H., Chugh, S. S., Albert, C. M., Kalman, J. M., \& Sanders, P. (2019). Epidemiology of sudden cardiac death: Global and regional perspectives. Heart, Lung and Circulation, 28(1), 6-14. https://doi.org/10.1016/j.hlc.2018.08.026

33. World Health Organization. (2018). Global Health Observatory (GHO) data. https://www.who.int/gho/mortality_burden_disease/causes_death/top_10/en/

34. Xie, L., Huang, S. F., \& Hu, Y. Z. (2015). Factors influencing pre-hospital delay in 
patients with acute myocardial infarction. Chinese Nursing Research 2.

35. Youssef, G. S., Kassem, H. H., Ameen, O. A., Taaban, H. S. Al, \& Rizk, H. H. (2017). Pre-hospital and hospital delay in patients with non-ST elevation acute coronary syndromes in tertiary care. The Egyptian Heart Journal, 69(3), 177-181. https://doi.org/10.1016/j.ehj.2017.01.002

36. Yusniawati, Y. N. P., Yueniwati, Y., \& Kartikawatiningsih, D. (2018). Knowledge and socioeconomic status as the factors of pre-hospital delay in patients with acute coronary. Research Journal of Life Science, 5(1), 34-41. https://doi.org/10.21776/ub.rjls.2018.005.01.4 